\title{
TYDEID MITES ON PERSIMMONS
}

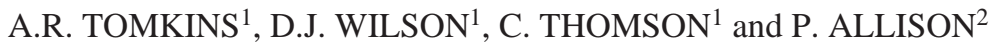 \\ ${ }^{1}$ HortResearch, Ruakura Research Centre, Private Bag 3123, Hamilton
${ }^{2}$ HortResearch, Te Puke Research Centre, RD 2, Te Puke
}

\begin{abstract}
Tydeid mites (Orthotydeus californicus and O. caudatus) occasionally contaminate persimmon fruit. Their abundance and phenology on fruit from persimmon (Diospyros kaki) trees in Whangarei, Pukekohe, Morrinsville, Bay of Plenty and Gisborne was investigated over three seasons (1995/96, 1996/97 and 1997/98). Few mites were found on fruit from all districts except Bay of Plenty and Gisborne. Fruit contamination began in December, peaked in February, declined from March or April and varied considerably between seasons. Mite abundance on persimmon trees was not related to their proximity to poplar shelter trees, a suspected source of the mites.
\end{abstract}

Keywords: Diospyros kaki, tydeid mites, Orthotydeus californicus, O. caudatus.

\section{INTRODUCTION}

Two species of tydeid mites, Orthotydeus californicus (Banks) and $O$. caudatus (Duges) can occur on apples (Bayan 1986), citrus (Garcia et al. 1986), persimmons (Tomkins et al. 1997), plums (Nachev and Simova 1978) and stonefruit (Castagnoli et al. 1984; Ferreira and Carmona 1997; Jones and Waddell 1996;McLaren et al. 1999). They appear to be generalist feeders which may occasionally feed on plant material but have not been reported to cause crop damage. As some export markets require crops free from these mites, pre-harvest (Tomkins et al. 1997) and post-harvest (Jones and Waddell 1996) control measures have had to be developed.

The New Zealand persimmon industry is introducing an Integrated Pest Management (IPM) system, commonly referred to as Green\&Gold. In order to develop this system, the ecology of the insects and mites which occur on persimmon has required study. This paper reports on the incidence of tydeid mites on persimmons.

\section{METHODS}

Samples of leaves and fruit were collected from one or two commercial orchards in Pukekohe, Maketu (Bay of Plenty) and Gisborne, and abandoned orchards in Whangarei and Morrinsville. The trees in commercial orchards had been treated with a full season export spray programme until the season before sampling began whilst those in the abandoned orchards had not been sprayed for at least one year previously. More details of the orchards and sampling are described in Tomkins et al. (2000). Fruit samples were collected from each orchard at two to three-weekly intervals from December until April/May in each of three seasons (1995/96, 1996/97 and 1997/98). At each orchard, either five or ten fruit were sampled from up to 40 trees on each sampling date. Five leaves were also randomly sampled from each of 20 trees in a Gisborne orchard during the 1997/98 season. At a Morrinsville orchard, fruit were sampled by collecting ten fruiting shoots per tree until mid-January and then five fruiting shoots per tree for the remainder of the 1995/96 season. All samples were coolstored at $4^{\circ} \mathrm{C}$ until microscopically examined to determine infestation by tydeid mites. Mites became inactive on fruit during cool-storage. The number of mites per leaf or fruit and the position on fruit (calyx or skin) were recorded.

Data were analysed by ANOVA before and after square root transformation, with a paired t-test used to compare mite numbers in different parts of trees and blocks. 


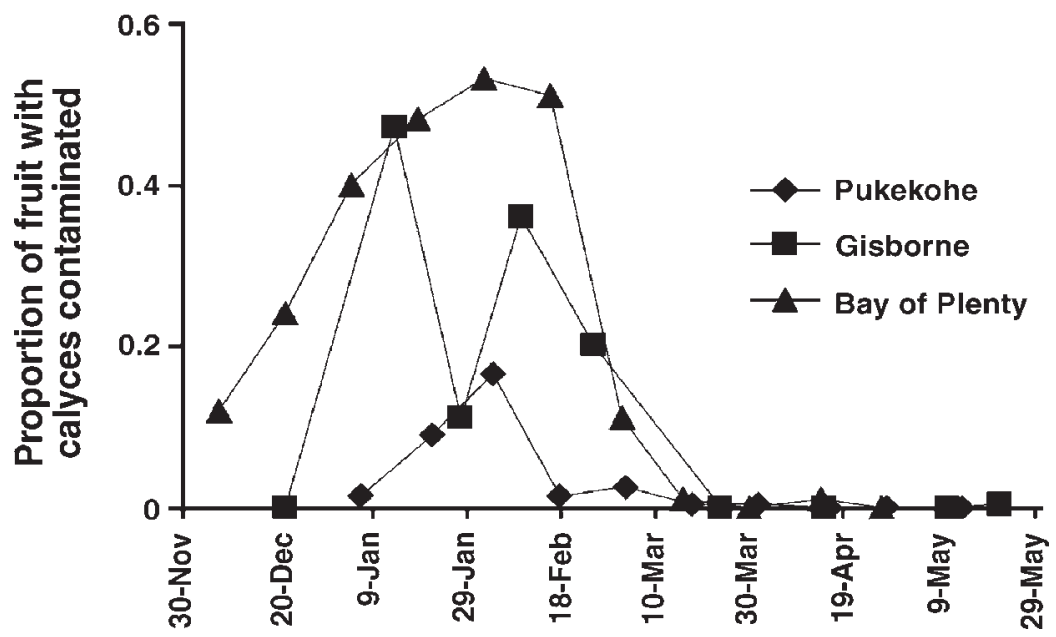

FIGURE 1: Proportion of fruit from persimmon orchards with calyces contaminated by tydeid mites in 1997/98.

\section{RESULTS AND DISCUSSION}

Fruit contamination by tydeid mites varied considerably between orchards and seasons (Table 1). In 1997/98 season, the highest level of fruit contamination was found in an orchard from Maketu (Fig. 1). However, the mean number of mites per infested fruit was consistently highest on fruit from a Gisborne orchard (Table 1), although fruit sampled from a second orchard in the same district in the 1995/96 season had a much lower level of contamination. Unpublished results from other trials also show that fruit contamination by tydeid mites is generally higher in Gisborne than other persimmon growing districts. Most contaminated fruit were only affected by a single tydeid mite, but up to 150 mites per fruit were recorded.

TABLE 1: Number of tydeid mites found per infested fruit on persimmons sampled from different growing districts.

\begin{tabular}{lcccc}
\hline District & Season & $\begin{array}{c}\text { No. of fruit } \\
\text { examined }\end{array}$ & $\begin{array}{c}\text { Tydeid mites per infested fruit } \\
\text { Mean }\end{array}$ & $\begin{array}{c}\text { Range } \\
\text { Whangarei }\end{array}$ \\
\cline { 1 - 2 } Morrinsville & $1996 / 97$ & 2023 & 1.23 & $1-4$ \\
& $1997 / 98$ & 1507 & 1.00 & 1 \\
Pukekohe & $1995 / 96$ & 2301 & 1.63 & $1-7$ \\
& $1996 / 97$ & 540 & 2.08 & $1-14$ \\
Katikati & $1997 / 98$ & 360 & 1.00 & 1 \\
& $1995 / 96$ & 2201 & 1.50 & $1-4$ \\
Maketu & $1996 / 97$ & 1999 & 4.98 & $1-86$ \\
Gisborne & $1997 / 98$ & 1985 & 1.72 & $1-7$ \\
& $1996 / 97$ & 200 & 1.38 & $1-3$ \\
& $1997 / 98$ & 1200 & 2.88 & $1-42$ \\
& $1995 / 96$ & 1442 & 16.55 & $1-131$ \\
& $1995 / 96$ & 1300 & 2.47 & $1-11$ \\
& $1996 / 97$ & 900 & 10.35 & $1-150$ \\
& $1997 / 98$ & 900 & 3.19 & $1-27$ \\
\hline
\end{tabular}




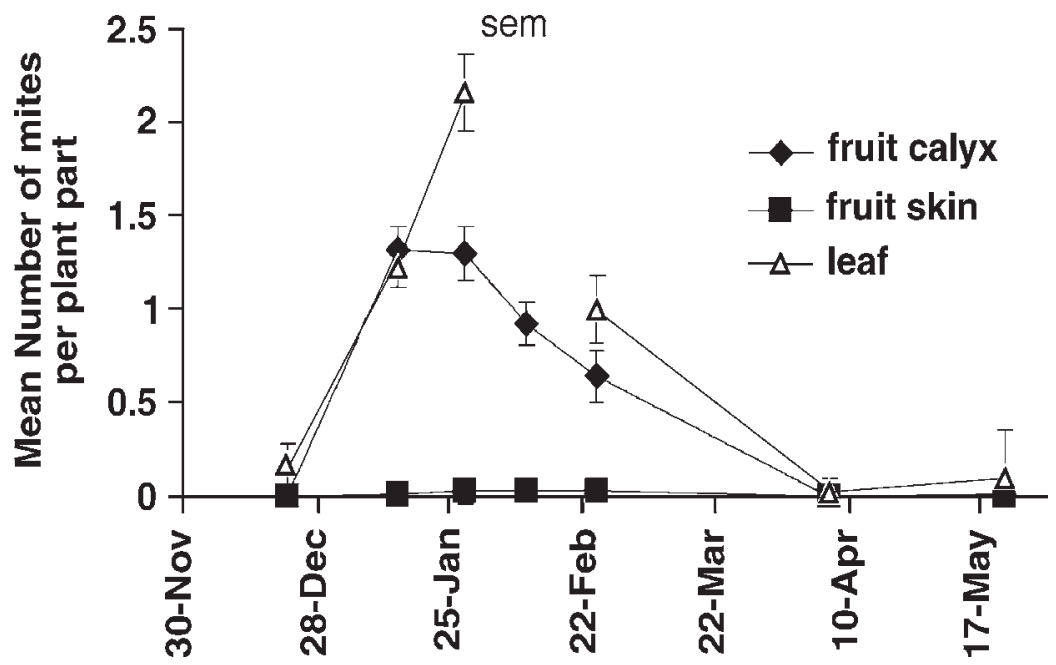

FIGURE 2: Mean number of tydeid mites per plant part on persimmon trees in Gisborne during 1997/98.

Tydeid mites were found contaminating fruit from as early as the first week in December (Fig. 1) until mid-May (Fig. 2). Typically their numbers increased rapidly during January and early February to peak between mid February and early March, and then began to decline (Fig. 2). The fall in the numbers of tydeid mites contaminating fruit usually occurred in early to mid-April, but in 1997/98 when mite populations were lower than normal (Table 1), their numbers declined unusually early at the beginning of March (Fig. 1). The sudden drop in mite numbers is important because persimmons are generally picked by a series of harvests beginning in mid-April. As a result, fruit harvested earlier will have a higher likelihood of being contaminated by tydeid mites. Similar observations have been made for mealybugs and thrips (Prestidge et al. 1989). In seasons or orchards when tydeid mites are relatively less abundant, their numbers increase later and decline earlier as in the Pukekohe orchard in 1997/98 season (Fig. 1).

Tydeid mites were found on leaves from the start of sampling in mid/late December but were not found on fruit until mid-January (Fig. 2). This delay in mites contaminating fruit may simply reflect the fact that leaves are present earlier. On fruit, almost all tydeid mites were found on the calyces rather than the skin (Fig. 2). The calyces are probably favoured because they provide a more protected place for the mites to shelter. As contamination begins earlier on leaves, leaf sampling is being used to monitor tydeid mite populations to determine both the need for and timing of chemical intervention (Tomkins et al. 1997). A monitoring and associated threshold system has been developed and is currently being trialled as part of the IPM system. This involves a single random sampling of 50 mature leaves per block in mid to late January, with a spray threshold of $25 \%$ of leaves contaminated.

The two species of tydeid mites $(O$. californicus and $O$. caudatus) which can occur on persimmon trees in New Zealand may feed on a wide range of material including other insects and mites, fungi, honeydew and plant tissues, although exactly what they eat on persimmon trees is unknown. It has been suggested that their abundance in persimmon orchards in Gisborne may be related to the common use of Lombardy poplar trees (Populus nigra L.) in the district. However, comparison of the numbers of tydeid mites found on trees sampled from rows at different distances from a poplar 


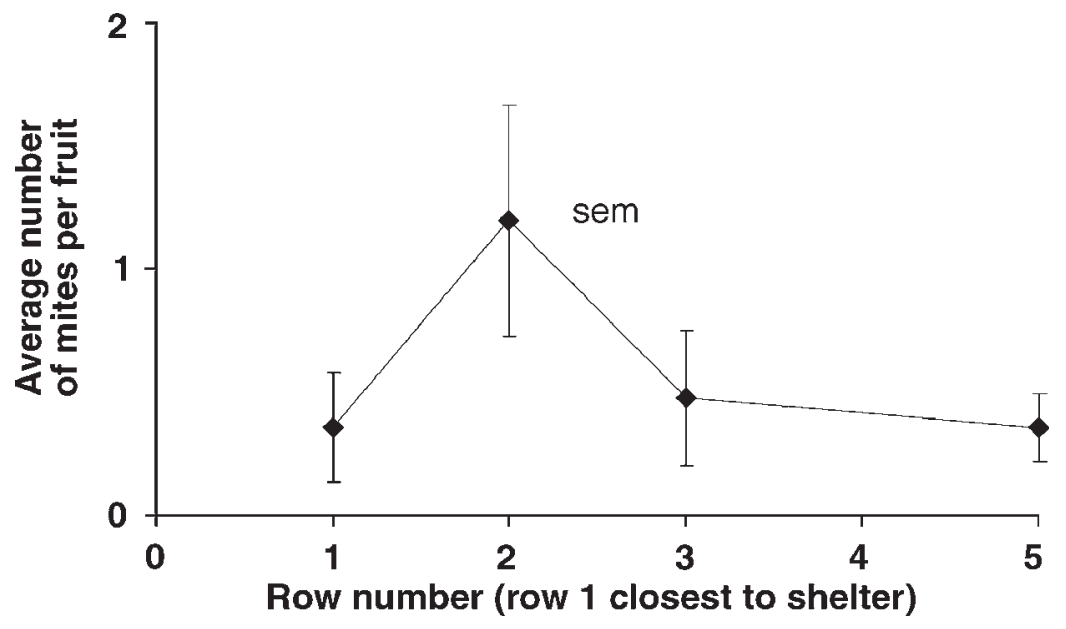

FIGURE 3: Average number of tydeid mites per fruit from persimmon trees in rows at different distances from a poplar shelterbelt in Gisborne on 16 February 1996.

shelterbelt in a block of persimmon trees in a Gisborne orchard gave no indication that numbers were related to the proximity of persimmon trees to the Lombardy shelter (Fig. 3). The numbers of tydeid mites on the poplar trees in the orchard in this current study were not determined. A previous study has shown that large populations of tydeid mites can occur on poplar leaves, but also found no indication that tydeid mite numbers were higher on adjacent persimmon trees (Brown and Lupton 1992). It is possible that the abundance of tydeid mites on persimmon trees in Gisborne is related to climate. The Gisborne region has hot, dry summers like other areas of New Zealand (e.g. Central Otago (McLaren et al. 1999)) and overseas (e.g. Italy (Castagnoli et al. 1984), Lebanon (Bayan 1986), Portugal (Ferreira and Carmona 1997) and Spain (Garcia et al. 1986)) where these species of tydeid mites are common.

\section{CONCLUSIONS}

Some important aspects of the ecology of tydeid mites which affect their management on persimmon trees have been identified. Although tydeid mites do not appear to cause any damage to persimmon trees, they need to be controlled to ensure that crops meet the phytosanitary requirement of some overseas markets. However, in some seasons and persimmon-growing regions, tydeid mite numbers will be too low to warrant any form of control. To ensure that sprays are only used against tydeid mites when their numbers warrant intervention, a system for monitoring tydeid mites on persimmon trees using leaf sampling has been developed in conjunction with a spray threshold.

\section{ACKNOWLEDGEMENTS}

Thanks to Persimmon Industry Council and AGMARDT for funding these studies, to Messrs S. Bent, B. Cooper, P. Coppock, J. Grahame, T. Lupton, G. Tombleson, O. van Leuuwen, L. Wells and B. Wilcox for providing trees and/or collecting samples and dispatching them to the authors at HortResearch, Ruakura Research Centre; to Mr. S. Hutchings for technical assistance and to Mr H. Henderson for statistical analysis. 


\section{REFERENCES}

Bayan, A., 1986. Tydeid mites associated with apples in Lebanon (Acari: Actinedida: Tydeidae). Acarologia 27: 311-316.

Brown, N.S. and Lupton, T.S., 1992. Control of tydeid mites in persimmons. Report to AGMARDT. Lewis \& Wright, Gisborne. $11 \mathrm{pp}$.

Castagnoli, M., Liguori, M., Nannelli, R., 1984. Contribution to the knowledge of peach mites in Tuscany and observations on the progress of their populations. Redia 47: 493-504.

Ferreira, M.A. and Carmona, M.M., 1997. The mite fauna of peach trees in Portugal. Boletin de Sanidad Vegetal Plagas 23: 473-478.

Garcia, M.F., Ferragut, F., Marzal, C., Costa, C.J., Laborda, R., 1986. Mites which live in the foliage of Spanish citrus trees. Investigacion Agraria, Produccion $y$ Proteccion Vegetales 1: 219-250.

Jones, V.M. and Waddell, B.C., 1996. Mortality responses of tydeid mite following hot water treatment. Proc. 49th N.Z. Plant Prot. Conf:: 21-26.

McLaren, G.F., Grandison, G., Wood, G.A., Tate, G. and Horner, I., 1999. Summerfruit in New Zealand. Management of pests and diseases. University of Otago Press. $136 \mathrm{pp}$.

Nachev, P. and Simova, S., 1978. Study on mites of plants in Bulgaria. 2. Species of the family Tydeidae in plum trees. Gradinarska I Lozarska Nauka 15: 20-32.

Prestidge, R.A., Holland, P.T., Clarke, A.D. and Malcolm, C.P., 1989. Pesticides for use close to and during harvest of persimmons. Proc. 42nd N.Z. Weed and Pest Control Conf: : 195-199.

Tomkins, A.R., Lupton, T., Brown, N., Wilson, D.J. and Thomson, C., 1997. Tydeid mite control on persimmons. Proc. 50th N.Z. Plant Prot. Conf.: 414-419.

Tomkins, A.R., Wilson, D.J., Thomson, C. and Allison, P.A., 2000. Armoured scale insects on persimmons. N.Z. Plant Prot. 53: 211. 